\title{
Feasibility Study of 3P Implementation in Handling Solid Waste by Empowering Housewives
}

\author{
${ }^{1}$ Marniati Marniati, ${ }^{2}$ Enda Silvia Putri, ${ }^{2}$ Itza Mulyani, ${ }^{2}$ Teuku Muliadi, ${ }^{2}$ Khairunnas Khairunnas, ${ }^{3}$ Cokorda Istri Dharmayanti, \\ ${ }^{4}$ Nur Nadiah
}

${ }^{1}$ Department of Public Health, Faculty of Public Health, Universitas Teuku Umar, Indonesia

${ }^{2}$ Department of Nutrition, Faculty of Public Health, Universitas Teuku Umar, Indonesia

${ }^{3}$ Faculty of Public Health, Universitas Bali Internasional, Indonesia

${ }^{4}$ Faculty of Education Teknikal and Vokasional, Universiti Tun Hussein Onn, Malaysia

Corresponding author: Marniati, e-mail:marniati@utu.ac.id

Co-author : ESP: endasilviaputri@utu.ac.id,_I.M.: Itzamulyani@utu.ac.id, TM: Teukumuliadi@utu.acid,KK:khainnnas@utuacid cokti.dharmayanti@gmail.com, NH:numadiahbteismail@gmail.com

Submitted:09/06/2021 Revised: 21/09/2021 Accepted: 27/09/2021 Published online: 20/10/2021

\begin{abstract}
DOI:https://doi.org/10.35308/j-kesmas.v7i2.3676 How to cite this article: Marniati,M., Putri,E.S., Mulyani,I., Muliadi,T., Khairunnas,K., Dharmayanti,C.I., Nadiah. N (2021). Feasibility study of 3P Implementation in Handling Solid Waste by Empowering Housewives. J-Kesmas: Jurnal Fakultas Kesehatan Masyarakat (The Indonesian Journal of Public Health). 8(2): $23-28$.
\end{abstract}

\begin{abstract}
The empowerment of homemakers has a significant effect on the Implementation of Extermination Transport Collection in handling solid waste to improve the cleanliness of the residential environment. The problem in this study is the low Implementation of 3P, where garbage collection is not left correctly scattered; the Transportation of garbage is not routine every day so that the garbage is scattered. Garbage is not destroyed as often as possible so that it harms health. This study aims to assess the feasibility of implementing 3P in dealing with solid waste by empowering homemakers in Drien Rampak Village, Johan Pahlawan District, West Aceh Regency. This research is a sectional observational study with one group pretest post-test design. I conducted in October 2020, which became the population of housewives with a total sample of 45 people. The study results show differences before and after measuring the 3P Implementation with the empowerment of homemakers in improving the cleanliness of the residential environment, as evidenced by the value (Probability 0.000) where there is a difference before and after measurement with a mean value of -1.622 . The 3P Implementation by empowering homemakers is feasible. Suggestions for continuing to empower the role of homemakers in implementing 3P solid waste to improve the quality of cleanliness in residential environments.
\end{abstract}

Keywords: 3P Implementation; Solid Waste; Empowerment; Housewives,

\section{Introduction}

The environment is a combination of physical conditions that include the state of natural resources such as land, water, solar energy, minerals, and flora and fauna that grow on land and in the oceans, with institutions that include human creation such as decisions on how to use the physical environment. According to (Zhang R. et al., 2019), physical environment characteristics need consistent support as prospective investigations are needed. The environment can also be interpreted as everything around humans and influences the development of human life, which consists of abiotic and biotic components. The abiotic component is everything lifeless: soil, air, water, climate, humidity, light, and sound. In contrast, the biotic component is everything animate such as plants, animals, humans and micro-organisms. An environment is a spatial unit with all objects, forces, conditions, and living things, including humans and their behaviour, which affect the continuity of life and the welfare of humans and living things. Research (Andesta, D. 2020) says it is necessary to properly utilize household organic waste to not cause problems for the surrounding environment.

The environment can be said to be everything around humans or living things that have a reciprocal and complex relationship and influence each other between one component and another. The home environment is a place around the residence where the environment can affect a person from their interactions, lifestyle and habits (Yarmaliza, Y., \& Marniati, M. 2017). The home environment has a vital role in disease transmission to residents and the surrounding community (Marwanty. M., \& Miko Wahyono. T.Y 2019). Damage to the environment occurs due to natural factors due to the ignorant hands of humans who are not environmentally friendly (Sofiani, S. S., \& Saefuloh, D. 
2019). These natural disasters can be floods, landslides, tsunamis, hurricanes, volcanic eruptions, or earthquakes. Besides being dangerous for the safety of humans and other creatures, this disaster will damage the environment.

According to (Ahya R. et al., 2020), environmental care is an essential aspect of teaching students and fostering understanding about the environment so that they have the attitude always to protect and preserve the environment. Environmental damage caused by human activities can be in the form of environmental impacts that impact public health (Sriwahyuni, S. et al., 2020), illegal logging causes floods or landslides, and garbage dumping in any place, especially river and sea flows will cause pollution. The behaviour of the community in maintaining the cleanliness of the environment around the house tends to throw garbage into the trenches around the house (Hardiana, D. 2018).

With the interaction between humans and the development of life, their needs will also be very developed, including the need for excessive exploitation of natural resources (Wang, I. J., \& Bradburd, G. S. 2014). According to research by Hasibuan, R. (2016). Garbage or household waste is garbage that comes from daily activities in the household besides feces and specific waste. The effect of household waste can affect environmental pollution, such as decreasing water quality, which will impact the health status of the surrounding community.

The problem that occurs in the environment around the community at this time is that solid waste is left scattered around the community's house even though there are trash bins for each resident's house, garbage transportation is not routine every day so that garbage piles up, garbage is not destroyed as often as possible. Based on the above problems, it is necessary to research environmental control around the house with a "3P Implementation Feasibility Study in handling solid waste by empowering housewives" in the community of Drien Rampak Village, Johan Pahlawan District, West Aceh Regency in improving the cleanliness of the environment around the house.

\section{Methods}

This type of research is an observational crosssectional study with a one-group pretest-posttest design. This study only uses one group, where before conducting the research, socialization related to the behaviour of respondents in implementing the 3Ps is given. Respondents were given a questionnaire as a post-test. To see changes by observing two times for one month after socialization. This research was conducted in October 2020 in Drien Rampak Village,
Johan Pahlawan District, West Aceh Regency. The population is 45 housewives. Sampling used a total sampling technique, which is a sampling technique by taking all population members as a sample (Sugiono, 2010), namely 45 homemakers.

\section{Results}

Table 1. Frequency distribution before the Empowering Housewives

\begin{tabular}{lll}
\hline Variables & frequency & \% \\
\hline Collection & & \\
Yes & 28 & 62,2 \\
No & 17 & 37,8 \\
Transport & & \\
Yes & 29 & 64,4 \\
No & 16 & 35,6 \\
Extermination & & \\
Yes & 30 & 66,7 \\
No & 15 & 33,3 \\
Implementation & & \\
Yes & 8 & 17,8 \\
No & 37 & 82,2 \\
\hline
\end{tabular}

(Primary Data, 2021)

From the table above, it can be seen that before the measurement of empowering homemakers in the Implementation of 3P shows that out of 45 respondents, there are $28(62.2 \%)$ respondents who do a waste collection. In contrast, 17 (37.8\%) do not collect waste. From the table above, it can be seen before the measurement of the empowerment of homemakers in Implementation that of the 45 respondents who carried out the Transportation of waste, there were $30(66.7 \%)$.

In contrast, $16(35.6 \%)$ did not carry out the Transportation. This type of research is a sectional observational study with one group pretest post-test design. This research was conducted in October 2020. The population was housewives with a sample of 45 homemakers in Drien Rampak Village, Johan Pahlawan District, West Aceh Regency. According to the table above,' before measuring the empowerment of housewives in the Implementation of the Destruction, only $30(66.7 \%)$ of the 45 respondents $(66.7 \%)$ did culling while $15(33.3 \%)$ did not destroy the waste. Before measuring the implementation table above, it can be seen that of the 45 respondents in the neighbourhoods, only $8(17,8 \%)$ were there to implement the $3 \mathrm{P}$ while $37(82.2 \%)$ respondents did not implement the 3P.

Following are the univariate results. After measuring the empowerment of homemakers in the Implementation of 3P, it turns out that far changes that 
have occurred in the environment around residential areas can be seen from the table below.

Table 2. Frequency distribution After the Empowering Housewives

\begin{tabular}{lll}
\hline Variables & Frequency & \% \\
\hline Collection & & \\
Yes & 44 & 97,8 \\
No & 1 & 2,2 \\
Transport & & \\
Yes & 43 & 95,6 \\
No & $\mathbf{2}$ & $\mathbf{4 , 4}$ \\
Extermination & & \\
Yes & 44 & 97,8 \\
No & 1 & 2,2 \\
Implementation & & \\
Yes & 22 & 48,9 \\
No & 23 & 51,1 \\
\hline Primary Data, 2021)
\end{tabular}

(Primary Data, 2021)

From the table above, it can be seen that after the measurement of the collection variable, there was a change in the better, namely from 45 respondents who did the collection reached $44(79.8 \%)$ while only 1 (2.2\%) did not collect. Based on the results above, the transportation variable obtained after the measurement was carried out could increase to $43(95.6 \%)$ of the respondents doing the Transportation. In comparison, the respondents who did not collect were only 2 (4.4\%).

The table above shows the changes that occurred after measuring the extermination variables, namely from 45 respondents reaching $44(97.8 \%)$ of the respondents who did the Destruction. In contrast, only 1 (2.2\%) of the respondents did not do the culling. The implementation table above after the measurement shows that out of 45 respondents, there were $22(48.9 \%)$ of the respondents had implemented the 3P. In contrast, $23(51.1 \%)$ of the respondents did not implement the 3P in the settlements of the surrounding population.

Table 3. Deep Collection 3P Implementation

\begin{tabular}{lcccc}
\hline \multicolumn{1}{c}{ Variable } & Mean & SD & SE & $\boldsymbol{\alpha}$ \\
\hline Measurement I & 14,17 & 4,696 & 0,700 & 0,001 \\
Measurement II & 19,33 & 6,139 & 0,915 & \\
\hline (Primary Data, 2021 & & & &
\end{tabular}

Table 4. Transportation Variable before and after measuring the empowerment of housewives

\begin{tabular}{lcccc}
\hline \multicolumn{1}{c}{ Variable } & Mean & SD & SE & $\boldsymbol{\alpha}$ \\
\hline Measurement I & 12,72 & 4,161 & 0,635 & 0,000 \\
Measurement II & 17,02 & 2,554 & 0,381 & \\
\hline
\end{tabular}

(Primary Data, 2021)
Table 5. Annihilation in 3P

\begin{tabular}{lcccc}
\hline \multicolumn{1}{c}{ Variable } & Mean & SD & SE & $\boldsymbol{\alpha}$ \\
\hline Measurement I & 13,82 & 5,069 & 0,756 & 0,000 \\
Measurement II & 17,31 & 2,521 & 0,376 & \\
\hline \multicolumn{4}{l}{ Primary Data, 2021) }
\end{tabular}

Table 6. Implementation $3 \mathrm{P}$

\begin{tabular}{lcccc}
\hline \multicolumn{1}{c}{ Variabel } & Mean & SD & SE & $\boldsymbol{\alpha}$ \\
\hline Measurement I & 5,29 & 1,902 & 0,284 & 0,000 \\
Measurement II & 6,91 & 1,345 & 0,201 & \\
\hline \multicolumn{4}{l}{ (Primary Data, 2021) }
\end{tabular}

Table 3. shows that the average collection score in the first measurement before being empowered by housewives in Implementation was 14.17 with a Standard Deviation of 4.696. In contrast, in the second measurement, an average was obtained 19.43 with a standard deviation of 6.239 . The mean value before measurement and after measurement was -5.156 . Therefore, both groups have a probability value of 0.001 . It can be concluded that there are differences before and after empowering homemakers in implementing the 3Ps in handling solid waste.

Based on table 4, it is known that the average score of Transportation in the first measurement is 12.72 with a standard deviation of 4.161 , while in the second measurement, the average score is 17.02 with a standard deviation of 2.554. The mean value before treatment and after treatment was $-4,289$. Therefore, both groups have a probability value of 0,000 . It can be concluded that there is a difference between Freight in the first measurement and Transportation in the second measurement.

According to table 5, the mean score of Destruction in the first measurement is 13.82 with a standard deviation of 5.069. In the second measurement, an average score is 17.31 with a standard deviation of 2.521. The mean value of the difference before measurement and after the measurement is -3.489 . Therefore, both groups have a probability value of 0,000 . It can be concluded that there is a difference between Destruction on the first measurement and Destruction on the second measurement.

Based on table 6, it is known that the average score of Implementation in the first measurement is 5.29, with a standard deviation of 1.902. In contrast, the Implementation in the second measurement is obtained an average score of 6.91 with a standard deviation of 1.345. The mean value of the difference between the first measurement and the second measurement is 1.622. Therefore both groups have a Probability value of 0.000 . It can be concluded that there are differences 
in Implementation in the first measurement with Implementation in the second measurement.

\section{Discussion}

\section{Collection}

Based on the research results, Transportation before empowerment of homemakers and after empowerment is much different, where before empowerment, the results are lower than Transportation after empowerment of homemakers. Of the 45 respondents, before the empowerment was carried out, only 28 people were there to collect, while after the empowerment was carried out, 44 people did the collection. Therefore, both groups have a probability value of 0.001 . It can be concluded that there is a difference between the collection in the first measurement and the collection in the second measurement.

According to (Thürer, M, et al., 2019), garbage collection is classified as a supply control problem with meticulous material flow and stochastic demand. Waste is the process of taking from the container/storage area from the source of the waste pile to the temporary collection point/transfer station. To solve this problem, (Ling J et al., 2018) propose a garbage collection deferral scheme. Garbage collectors in our buffer collect garbage objects while avoiding infinite regression and unacceptable memory consumption. We implement the Schema subset interpreter that supports buffered garbage collection and evaluates its memory efficiency. (McEwan, A. A., \& Komsul, M. Z. 2018). According to research (Jimmyanto, H. et al., 2017) said the measurement of the average weight of waste generation according to the results of the evaluation is that the container system is still in a mixed state, this collection system is due to the lack of a service system at the TPS.

\section{Transport}

Based on the research results, Transportation before the empowerment of homemakers is lower than Transportation after empowerment of homemakers. Of the 45 respondents, before the empowerment was carried out, only 29 people carried out the Transportation, while after the empowerment was carried out, 43 people carried the Transportation. Therefore both groups have a Probability value of 0.000 . It can be concluded that there is a difference between Freight in the first measurement and Transportation in the second measurement.

Transportation of solid waste is a process whose goal is to carry waste from the transfer location or the waste source directly to the final processing site. Research (Sulemana et al., 2020) that waste collection can be achieved through route optimization in a geographic information system (GIS) environment. Mode of Transportation and determine the frequency of Transportation during the planning period. Research (Rızvanoğlu, et al, 2020). Garbage is one of the important causes of the environmental crisis, which negatively impacts human health worldwide and is rapidly approaching a level of disaster that will directly threaten human life. Environmental impact of the gas released during the transport of solid waste in a company from Santa Catarina (Voss, B et al., 2012). The domestic solid waste transportation system that has been implemented has not looked optimal, such as the transportation schedule and the number of transportations. The best route should be made according to the time and distance of Transportation (Rusmaya, D. et al., 2019).

\section{Extermination}

The results showed that the Destruction before empowerment of homemakers was lower than the Destruction after empowerment of homemakers. Of the 45 respondents, before the empowerment was carried out, only 30 people did the Destruction, while after the empowerment was carried out, 44 people did the Destruction. Therefore both groups have a Probability value of 0.000 . It can be concluded that there is a difference between Destruction on the first measurement and Destruction on the second measurement.

Waste at source locations (households, industry, offices, hotels and so on) is placed in temporary storage for easy disposal. Adzawla W. et al. (2019) said that solid waste management remains a significant challenge in Ghana, especially in suburban and urban areas. The implications of this bottleneck are widely recognized. Nonetheless, fundamental issues such as the factors that encourage households to adopt specific solid waste disposal systems have not been explored. In the literature, studies that focus on solid waste disposal generally consider thermal recovery methodologies, biological, or only specific to solid waste technologies used in certain countries, cities or regions (Arıkan, E. et al., 2017). Poor solid waste management is increasingly taking a hegemonic position in urban policy discourse in Ghana. (Alhassan et al., 2020). According to Leuhery, L. (2011), the quality of management carried out will determine the quality/degree of existing environmental health by prioritizing reliability. 


\section{Conclusion}

The Implementation of 3P with the empowerment of homemakers is feasible. There is a significant difference before the pretest and post-test are carried out on the 3P Implementation with the Empowerment of Housewives in maintaining cleanliness around the surrounding community settlements Drien Rampak Village, Johan Hero District, West Aceh Regency.

\section{Acknowledgement}

They are making the surrounding environment a clean environment free of garbage by socializing the importance of protecting the environment with the participation of disposing of garbage to supervise it so that handling, maintenance and repair can be carried out appropriately to increase public awareness to live clean, in order to continue to empower the role of homemakers in the Implementation of solid waste $3 \mathrm{P}$ in order to improve the quality of cleanliness in residential environments.

\section{Author Contribution and Competing Interest}

State the authors' contribution and roles in the research and in preparing this manuscript. Please also mention competing interests (if any).

\section{References}

Adzawla, W., Tahidu, A., Mustapha, S., \& Azumah, S. B. (2019). Do socioeconomic factors influence households' solid waste disposal systems? Evidence from Ghana. Waste Management and Research, 37(1_suppl), 5157.https://doi.org/10.1177/0734242X18817717

Ahya, R. R., Syaharuddin, S., \& Rahman, A. M. (2020). The Caring Attitudes for Environment of Lanting Householders as a Learning Resource on Social Studies. The Innovation of Social Studies Journal, 2(1), 66.

https://doi.org/10.20527/iis.v2i1.2314

Alhassan, H., Kwakwa, P. A., \& Owusu-Sekyere, E. (2020). Households' source separation behaviour and solid waste disposal options in Ghana's Millennium City. Journal of Environmental Management, 259. https://doi.org/10.1016/j.jenvman.2019.110055

Andesta, D. (2020). Pemanfaatan Limbah Sampah Rumah Tangga Menjadi Pupuk Organik Di Desa Banjarmadu. DedikasiMU(Journal of Community Service), 2(2), 307. https://doi.org/10.30587/dedikasimu.v2i2.1427

Arıkan, E., Şimşit-Kalender, Z. T., \& Vayvay, Ö.
(2017). Solid waste disposal methodology selection using multi-criteria decision-making methods and an application in Turkey. Journal of Cleaner Production, 142, 403-412. https://doi.org/10.1016/j.jclepro.2015.10.054

Hardiana, D. (2018). Perilaku Masyarakat dalam Menjaga Kebersihan Lingkungan Pantai Kecamatan Sasak Ranah Pasisie Kabupaten Pasaman Brat. JURNAL BUANA, 2(2), 495. https://doi.org/10.24036/student.v2i2.98

Hasibuan, R. (2016). Analisis dampak limbah/sampah rumah tangga terhadap pencemaran lingkungan hidup. Jurnal Ilmiah Advokasi, 4(1), 42-52. https://doi.org/10.1016/j.micpro.2017.10.008

Inghels, D., Dullaert, W., \& Vigo, D. (2016). A service network design model for multimodal municipal solid waste transport. European Journal of Operational Research, 254(1), 68-79. https://doi.org/10.1016/j.ejor.2016.03.036

Jimmyanto, H., Zahri, I., Dahlan, M. H., \& Putri, S. N. R. (2017). Evaluasi Sistem Pengelolaan Sampah Padat Domestik Di Kota Palembang Tahun 2017. Demogrphy Journal of Sriwijaya, 6(1), 17.

M., \&. Y. (2018). The Social and Cultural Capital Exploration Keeping Personal Hygiene in Children. International Journal of Engineering \& Technology, 7(2.29), 498. https://doi.org/10.14419/ijet.v7i2.29.13807

Marniati, M. (2017, November). Identifikasi Sosial Budaya Ibu terhadap Pencegahan Diare pada Balita. In Prosiding SEMDI-UNAYA (Seminar Nasional Multi Disiplin Ilmu UNAYA). 1(1): 146-154.

Marniati, M., \& Yarmaliza, Y. (2017, October). Analisis Faktor Penyebab terhadap Kejadian ISPA. In Prosiding Seminar Nasional USM. 1(1).

Marniati, M., Putri, E. S., Sriwahyuni, S., Khairunnas, K., \& Duana, M. (2020). Knowledge Study, Income Level and Socio-Culture of the Nutritional Status of the toddler. Journal of Nutrition Science, 1(2).

Marwanty, M., \& Miko Wahyono, T. Y. (2019). Faktor Lingkungan Rumah dan Kejadian Demam Berdarah Dengue di Kota Palopo 2016. Jurnal Epidemiologi Kesehatan Indonesia, 2(1). https://doi.org/10.7454/epidkes.v2i1.3106

McEwan, A. A., \& Komsul, M. Z. (2018). Age Aware Pre-emptive Garbage Collection for SSD RAID. Microprocessors and Microsystems, 56, 13-21.

Ouyang, Z., Wei, W., \& Chi, C. G. (2019). Environment management in the hotel industry: does institutional environment matter? International Journal of Hospitality 
Management, 77,

https://doi.org/10.1016/j.ijhm.2018.07.015

Rızvanoğlu, O., Kaya, S., Ulukavak, M., \& Yeşilnacar, M. İ. (2020). Optimization of municipal solid waste collection and transportation routes through linear programming and geographic information system: a case study from Şanlıurfa, Turkey. Environmental Monitoring and Assessment, 192(1). https://doi.org/10.1007/s10661-019-7975-1

Rusmaya, D., Rochaeni, A., \& Mulyana, H. (2019). Perencanaan Jalur Pengangkutan Sampah di Kabupaten Bogor, Kota Bogor, dan Kota Depok Menuju Stasiun Pengumpul Antara (Spa). Journal of Community Based Environmental Engineering and Management, 2(1), https://doi.org/10.23969/jcbeem.v2i1.1450

Shi, X., Ke, Z., Zhou, Y., Jin, H., Lu, L., Zhang, X., ... Wang, F. (2019). Deca: A garbage collection optimizer for in-memory data processing. ACM Transactions on Computer Systems, 36(1). https://doi.org/10.1145/3310361

Sofiani, S. S., \& Saefuloh, D. (2019). Penggerak Niat Perilaku Pembelian Produk Fesyen Ramah Lingkungan dengan Teori Perilaku yang Direncanakan. Proceeding Industrial Research Workshop and National Seminar, 10(1), 767$776 . \quad$ Retrieved from https://jurnal.polban.ac.id/ojs-

3.1.2/proceeding/article/view/1516

Sriwahyuni, S., Hanifa, Marniati, Yarmaliza, \& Zakiyuddin. (2020). Pengaruh Pengetahuan Dan Lingkungan Terhadap Kejadian Filariasis Di Wilayah Kerja Puskesmas Lueng Keube Jagat Kecamatan Tripa Makmur Kabupaten Nagan Raya. Iakmi Jurnal Kesehatan Masyarakat Indonesia, 1(1), 1-6. https://doi.org/10.46366/ijkmi.1.1.1-6

Sulemana, A., Donkor, E. A., Forkuo, E. K., Asantewaa, J., Ankrah, I. N. A., \& Musah, A. M. O. (2020). Optimized routing of trucks for institutional solid waste collection in Kumasi, Ghana. Detritus, 9(March), 50-58. https://doi.org/10.31025/2611-4135/2020.13896
Thürer, M., Pan, Y. H., Qu, T., Luo, H., Li, C. D., \& Huang, G. Q. (2019). Internet of Things (IoT) driven kanban system for reverse logistics: solid waste collection. Journal of Intelligent Manufacturing, 30(7), 2621-2630. https://doi.org/10.1007/s10845-016-1278-y

Voss, B. de L., Pfitscher, E. D., Vicente, E. F. R., \& Ferreira, L. F. (2012). Disclosure of environmental impacts within the agribusiness chain: A study on the transport of solid waste in a city in Santa Catarina. Custos e Agronegocio, 8(3), 91-112.

Wang, I. J., \& Bradburd, G. S. (2014). Isolation by environment. Molecular Ecology. Blackwell Publishing Ltd. https://doi.org/10.1111/mec.12938

Yarmaliza, M. (2018). Study Analysis of Knowledge Mother and Environmental Conditions of Occurrence of Acute Respiratory Infections in Children. International Journal of Engineering \& Technology, 7(2.29), 491-493.

Yarmaliza, Y., \& Marniati, M. (2017, October). Pengaruh Lingkungan Terhadap Kejadian Diare Pada Balita. In Prosiding Seminar Nasional Usm. 1(1)

Zhang, R., Wulff, H., Duan, Y., \& Wagner, P. (2019, September 1). Associations between the physical environment and park-based physical activity: A systematic review. Journal of Sport and Health Science. Elsevier B.V. https://doi.org/10.1016/j.jshs.2018.11.002

Zhang, Y., Tzortzopoulos, P., \& Kagioglou, M. (2019). Healing built-environment effects on health outcomes: environment-occupant-health framework. Building Research and Information, 47(6), 747-766. https://doi.org/10.1080/09613218.2017.1411130 